\title{
Comparison of Soil-Pellet and Sieving-Floatation Methods for Enumeration of Sugarbeet-Root-Rot Fungus (Rhizoctonia solani AG 2-2)
}

\author{
Mitsuro HyakUmachi* and Tadao UI* \\ 百町満朗* ・宇井格生* : 土壌塊法と節別浮上法によるテンサイ根腐病菌 \\ (Rhizoctonia solani AG 2-2) の菌量の比較
}

Key Words : Rhizoctonıa solani AG 2-2, population, soil-pellet method, sieving-floatation method.

The dilution-plate method is widely used for determining populations of various microorganisms in soil. But this method has not been applied successfully to Rhizoctonia solani because of its relatively small numbers. Ways of detecting and enumelating $R$. solani in soil, are, the plant segment colonization method ${ }^{1-4)}$. the immersion tube $\operatorname{method}^{1,5)}$, the plant debris particle isolation method ${ }^{1,2)}$, the seedling infection method $^{2,3,5)}$ and the soil pellet method ${ }^{6)}$. All of these are indirect methods, making use of saprophytic or parasitic activity of the pathogen. The first four methods give approximate population density, while the last gives concrete numbers. Therefore, the last one is proper to determine the quantitative assay. On the other hand, the sievingfloatation $\operatorname{method}^{()}$is used as a direct method for enumeration. In this case, sclerotia are the only objects of the propagule unit of $R$. solani. After examining the viability of sclerotia extracted from soil, the propagule number (number of viable sclerotia) can be counted. This study was conducted in order to determine whether the soil pellet method (SPM) or the sieving floatation method (SFM) is more suitable for a quantitative assay of $R$. solani in a study on vicissitude of sugarbeet-root-rot in monoculture.

Thirteen soil samples were obtained from the soils around severely diseased roots (disease index 5) ${ }^{8)}$ in May 1981, after overwintering in the sugarbeet field where rootrot disease had occurred severely in the previous year.

SPM and SFM were compared to detect the enumeration of $R$. solani propagule in the soil. SPM was followed by Ko and Hora's method ${ }^{6}$. Ten $50-200 \mathrm{mg}$ soil pellets with $30 \%$ soil moisture were placed on a $9 \mathrm{~cm}$ Petri dish containing selective medium of $R$. solani. The percentage of appearance of $R$. solani hyphae from the soil pellet was sur-

* Faculty of Agriculture, Hokkaido University, Kitaku, Sapporo 060, Japan 北海道大学農学部 1) Davey, C. B. and Papavizas, G. C. (1962). Can. J. Microbiol. 8:847-853 2) Menzies, J. D. (1963). Ann. Rev. Phytopathol. $1: 127-142$. 3) Papavizas, G. C. and Davey, C. B. (1959). Plant Disease Reptr. $43:$ 404-410. 4) Ui, T. and Ogoshi, A. (1964). Mem. Fac. Agr. Hokkaido Univ. $5: 5-$ 16. 5) Martinson, C. A. (1963). Phytopathology $53: 634-638$. 6) Ko, W. H. and Hora, F. K. (1971). Ibid. $61: 707-710$. 7) Ui, T., Naiki, T. and Akimoto, M. (1976). Ann. Phytopathol. Soc. Japan $42: 46-48$. 
veyed, and the propagule number of $R$. solani was calculated in $100 \mathrm{~g}$ dry soil. One hundred soil pellets (ten petri dishes) were used per one soil sample. SFM was followed by Ui et al's method ${ }^{7}$. Thirty to fifty g of soil was stirred with $100 \mathrm{ml}$ of $2 \%$ aqueous solution of hydrogen peroxide. This soil suspension was poured through a 50 mesh sieve, and was washed under running tap water. Coarse particles remain ing on the sieve, including sclerotia and plant debrises, were then poured into a $500 \mathrm{ml}$ separating funnel with a $2 \%$ aqueous solution of hydrogen peroxide again, and were shaken vigorously. Floated sclerotia and plant debrises were placed on a filter paper, and the number of sclerotia was counted under a dissecting microscope. Extracted sclerotia were placed on the acidified water agar ( $\mathrm{pH} 4.5$ ). After two days incubation at $25 \mathrm{C}$, number of germinated sclerotia was counted, and the propagule number of $R$. solani was calculated in $100 \mathrm{~g}$ dry soil. Viability of sclerotia was evaluated from the percentage of germinated sclerotia out of all the sclerotia extracted from the soil.

The propagule number of $R$. solani obtained from the two methods were compared (Table 1). There was a high correlation between them $(r=0.857, p<0.01)$, and the propagule number obtained from SFM tended to be higher than that obtained from SPM. There were only two samples out of thirteen from which $R$. solani could not be detected by using SFM, and six samples by using SPM. There could also be seen a tendency that the propagule number of $R$. solani calculated by SPM was low in the soil of low sclerotial viability, while soils where $R$. solani was not detected were soils with less than $25 \%$ of sclerotial viabilty. One of the reasons for the above was considered

Table 1. Comparison of the data of inoculum density of Rhizoctonia solani AG 2-2 obtained from sieving-floatation and soil-pellet methods

\begin{tabular}{c|c|c|c|c}
\hline \hline \multirow{2}{*}{$\begin{array}{c}\text { Soil sample } \\
\text { number }\end{array}$} & \multicolumn{3}{|c}{ Sieving-floatation method } & Soil-pellet method $^{\text {a }}$ \\
\cline { 2 - 4 } & $\begin{array}{c}\text { Sclerotial } \\
\text { number/100g } \\
\text { dry soil }\end{array}$ & $\begin{array}{c}\text { Viable sclerotial } \\
\text { number/100g } \\
\text { dry soil }\end{array}$ & $\begin{array}{c}\text { Sclerotial viability } \\
(\%)\end{array}$ & $\begin{array}{c}\text { Propagules/100g } \\
\text { dry soil }\end{array}$ \\
\hline 1 & 1380 & 1173 & 85.0 & 580 \\
2 & 1120 & 840 & 75.0 & 180 \\
3 & 260 & 0 & 0.0 & 0 \\
4 & 260 & 0 & 0.0 & 0 \\
5 & 140 & 40 & 28.6 & 20 \\
6 & 1420 & 106 & 7.5 & 0 \\
7 & 6320 & 209 & 3.3 & 0 \\
8 & 720 & 144 & 20.0 & 60 \\
9 & 940 & 118 & 12.5 & 0 \\
10 & 520 & 130 & 25.0 & 100 \\
11 & 2940 & 735 & 25.0 & 40 \\
12 & 4260 & 426 & 10.0 & 0 \\
\hline
\end{tabular}

a) by Ui et al. $(1976)^{7)}$

b) by Ko and Hora $(1971)^{6)}$

8) Naiki, T. and Ui, T. (1977). Soil Biol. Biochem. 9 : 377-381. 9) Hyaikumachi, M. and Ui, T. (1982). Ann. Phytopathol. Soc. Jpn. $48: 628-633$. 
to be the low saprophytic colonizing ability of $R$. solani from the soil pellet to the selective medium, especially during early spring when most of sclerotia lost their viability. On the other hand, in SFM, sclerotia were directly extracted from the soil, and if there were many sclerotia, the propagule number could be easily estimated even when the sclerotial viability was extremely low provided that it was not $0 \%$.

From these results, SFM seems to be superior to SPM in estimating the propagule number of $R$. solani when saprophytic activity is low as it is in early spring. The viable sclerotia play an important role as the main inoculum of the sugarbeet root-rot fungus ( $R$. solani AG 2-2 $)^{9}$, therefore, SFM seems to be the most appropriate way to estimate the quantitative assay of this pathogen. 